\title{
Experiments on the buckling behaviour of glass columns. Part 1.
}

- kpankhardt@yahoo.com

ANDRÁs JAKAB - civil engineer, Üveg-Fémszer Kft. - jakabandreas@gmail.com

Salem Georges NEHME - Assoc. Prof., BME, Department of Construction Materials and Engineering Geology=sgnehme@yahoo.com

Érkezett: 2013. 10. 16. - Received: 16. 10. 2013. - http://dx.doi.org/10.14382/epitoanyag-jsbcm.2013.13

Institute; Hungarian Group of fib; Hungarian engineer chamber (MMK: 01-9160). Fields of interests: load bearing glasses, testing of construction materials, design, recycling of building materials.

\section{Abstract}

Supporting structures can be transparent nowadays due to the development of glass strengthening procedures. The building glass as a versatile building material supports architectural design due to its transparency. The paper focuses on load-bearing glass columns and also on the design, the load bearing capacity and the stability issues of fins. International and Hungarian case studies demonstrate the possible use of cross-sections, layers and supporting structures of glass columns [1]. Laboratory experiments were carried out at the BME, Department of Construction Materials and Engineering Geology on buckling of glass columns. More than 60 specimens where loaded until fracture. The load and deformations (buckling, surface deformations) were measured. Based on the experimental results, the critical force was determined and the fracture and stability processes were illustrated by force-deflection diagrams. The results were analysed with the calculation procedures in the focus of the international literature (results are presented separately in the 2 nd part of the present paper series).

Keywords: glass column, buckling, load bearing glass, stability, transparency

\section{Glass columns in structural hierarchy}

András JAKAB

MSc Civil Engineer, designer at Üveg-FémSzer Ltd. Fields of interests: glass construction, glass columns, construction technology and management.

Salem G. NEHME

MSc Civil Engineer, PhD, Associate Professor at the Department of Construction Materials and Engineering Geology, Budapest University of Technology and Economics (BME). Member of the Technical committee of Glass Working Group (MSZT/MB 112) of Hungarian Standardization Institute; Hungarian Group of fib; Hungarian engineer chamber (MMK: 01-9159). Fields of interests: concrete technology, mass concrete, self-compacting concrete, fibre reinforced concrete, quality control of building materials, non-destructive testing reinforced concrete structures, recycling of concrete.

Glass columns belong to the primary structural elements in the structural hierarchy of load bearing glasses (Fig. 1). Glass columns support the secondary and the tertiary elements, which structural elements transfer the load to the primary structural elements that carry the load $[1,2,3]$. The fracture of glass columns used in primary structural elements can cause stability problems in a building, therefore, researchers need to focus more on load bearing and stability questions.



Fig. 1. Hierarchy of structural elements [3, 4, 5]

1. ábra Tartószerkezetek hierarchiája $[3,4,5]$

Glass is used nowadays as a load bearing material due to its transparency, and usually is called the material of the third millennium. With the development of glass strengthening methods, glass has become a frequently used building material in load bearing structures as well [4].

Further investigations are required especially in those areas, where glass is used as a load bearing element. Glass is a brittle material and for a long time its brittleness was a well-known property besides its transparency.

With the development of glass strengthening methods, in the last few years glass began to also be a load bearing material for engineers, which raises several questions. Glass used in columns meet different requirements (to carry loads with limited deformations as well as to be aesthetic), although the structural design of load bearing glass structures is not standardised yet in Hungary.

\section{Cross-section of glass columns}

During the design of glass columns, engineers have to take into account beside standardised loads - due to the brittle behaviour of glass - special impact loads or non-standardised loads as well, e.g.: impacts that are originated from special concentrated loads: effect of soft-impact e.g. from people or hard-impact e.g. by falling objects. Therefore, it is preferred to carefully select the appropriate location of glass columns inside a building especially when it is used in public areas.

\subsection{Cross-section types}

Laminated safety glass should be used in load bearing glass columns: at least three layers of heat strengthened glass (HSG) and/or fully tempered glass (FTG) or combination of them is required. The thickness of the interlayer foil should be at least $0.76 \mathrm{~mm}$ (type of the interlayer material can be EVA or PVB). 

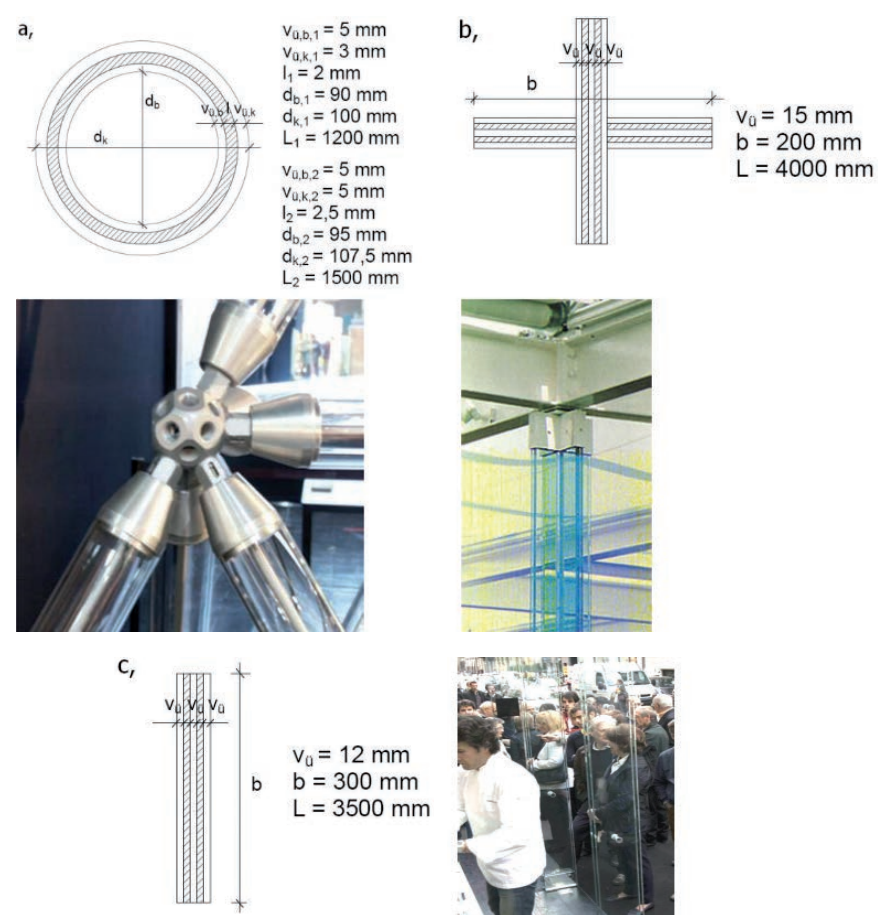

Fig. 2. Types of cross-sections $[1,6,7]$

2. ábra Keresztmetszet típusok $[1,6,7]$

The interlayer material serves two purposes: (1) to keep glass splinters in place during the fracture process to reduce the risk of injury and (2) to increase residual load bearing capacity.

Different shapes of cross-sections are used in glass columns (see Fig. 2) that can be distinguished as:

- Simple cross-sections: cross-section consisted of plane glass layers; circle shaped glass layers.

- Compound cross-sections: cross-section consisted of plane glass layers - square or cross shaped

\subsection{Single and multi-storey glass columns}

Glass columns can be designed as single or multi-storey structural elements. The type of the supporting structure depends on the height of the glass column. Supporting method can be:

- Glass columns fixed in the region of their lower and upper edges in so called "steel shoe" supporting element. In this case the buckling behaviour should be analysed.

- Suspended method to reduce the effect of buckling. This type of support is preferred to be used in multistorey façades, where the glass columns are mainly supported independently from the intermediate slabs. In this case the stresses in the region of the bore holes in the glass should be analysed.

\subsection{Coupling elements in multi-storey glass columns}

Nowadays, glass columns with more than $4 \mathrm{~m}$ height are designed in a safe way (Fig. 3 to Fig. 5), however over $6 \mathrm{~m}$ height, coupling elements should be placed.

In general, these coupling elements are constructed with the preparation of bore holes, with the use of screws and steel plates and damping materials. The EN 12150-1:2000 standard determines the requirements on spacing of bore holes in glass.
In recent laboratory experiments, researchers focus on glued glass coupling elements, with the use of overlapping glass layers in laminated glasses.

Main properties of suspended glass columns:

- Construction of glass façade with significant height is possible;

- The self weight and loads of the glazing of the façade are carried mainly by the upper coupling element of the glass column;

- Safety glass consisted of tempered glass layers should be used due to the high stress concentration in the bore hole regions;

- In the case of locations where earthquake with higher magnitude can occur, the glass columns should be suspended.

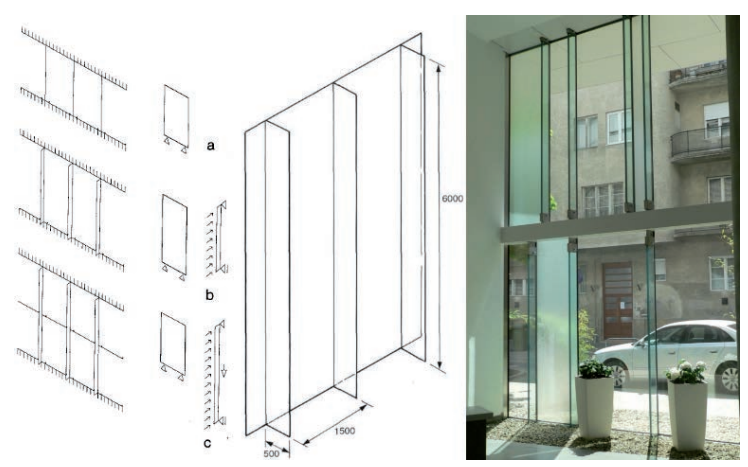

Fig. 3. Single and multi-storey glass columns [1,5]; Budapest, Viziváros Business centre, Glass columns of Residence 1 building (structural design: Dr. Kinga Nehme)

3. ábra Egy, ill. több szint magas üveg lizénák [1, 5]; Budapest, Vízivárosi irodaházak, Residence 1 épület üveg lizénái (statikus tervezö: Dr. Nehme Kinga)

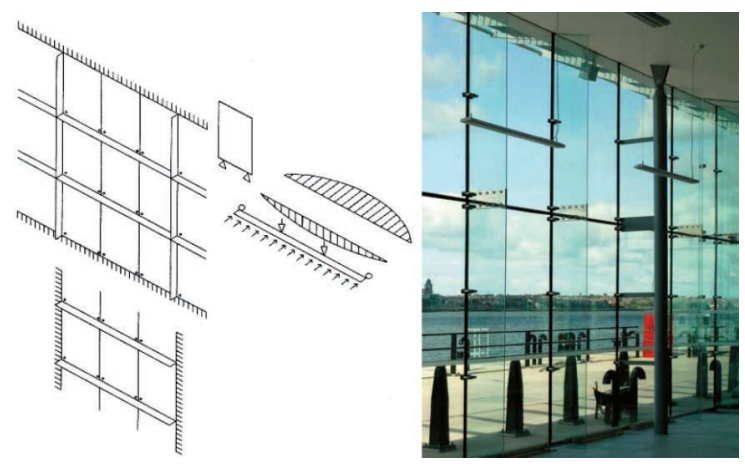

Fig. 4. Multi-storey glass columns with use of Pilkington Planar ${ }^{\mathrm{m}}$ coupling system [1, 8]: Cruise Liner Ferry Terminal, Liverpool, UK

4. ábra Több szint magas üveg lizénák Pilkington Planar ${ }^{\text {TM }}$ rögzitéssel [1,8]: Cruise Liner Ferry Terminal, Liverpool, UK

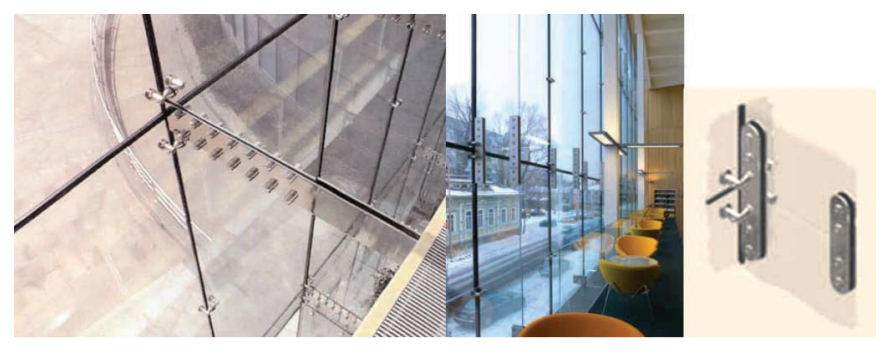

Fig. 5. Spacing of bore holes in vertical and horizontal directions (Library of Turku Finland) [8]

5. ábra Vizszintes és függőleges furatlyuk kiosztás (Turku könyvtár, Finnország) [8] 


\section{Laboratory experiments}

\subsection{Test parameters}

Laboratory experiments were carried out to study the buckling behaviour of single and laminated glass columns at the Department of Construction Materials and Engineering Geology, BME. The specimens were tested with use of INSTRON 5989 universal testing machine. All glass specimens were loaded in compression by concentrated load by variable specimen heights and a constant nominal width of $80 \mathrm{~mm}$. The buckling behaviour and the fracture process were recorded by high-speed digital camera.

Single layer float glass, single layer heat-strengthened glass and laminated glass consisted of both float and heat-strengthened glass layers were tested. Although single layer glass and float glass are usually not used in load bearing glass columns, the effect of heat-strengthening on the buckling behaviour can be studied and can be compared with existing calculation methods in this way. The geometry of test specimens (height, thickness, width) was chosen on the basis of experiences with existing glass columns in buildings in international and Hungarian references.

Test parameters of glass specimens were the followings:

Constants: test arrangement, the type of support; width of glass $(80 \mathrm{~mm}$ ); interlayer material (EVA foil with thickness of $0.38 \mathrm{~mm})$; edgework; temperature $\left(+23 \pm 5^{\circ} \mathrm{C}\right)$.

Variables: type of glass layers: HSG/ non heat-treated float; height of specimens: $1000 \mathrm{~mm} ; 920 \mathrm{~mm} ; 840 \mathrm{~mm}$; number of glass layers and the thickness of specimens: single layer: $8 \mathrm{~mm}$; $12 \mathrm{~mm}$, laminated: $2 \times 4 \mathrm{~mm} ; 2 \times 6 \mathrm{~mm} ; 8+4 \mathrm{~mm}$, laminated: $3 \times 4 \mathrm{~mm}$; The rate of loading: $0.5 \mathrm{~mm} / \mathrm{min} ; 1 \mathrm{~mm} / \mathrm{min}$.

Support: Height of fixing: $95 \mathrm{~mm}$; rubber plate (Shore A 80) was used between the steel supports and the glass.

Simplified designation is used to distinguish the studied specimens; e.g. $H \_2(4.4) \_2 \_920 \_0.5$,

where:

\begin{tabular}{|c|c|}
\hline $\mathrm{H}, \mathrm{F}:$ & Type of glass: \\
\hline & H - HSG; F - non heat-treated float glass; \\
\hline 2(4.4): & $\begin{array}{l}\text { Number of glass layers e.g.: } \\
2 \times 4 \text { mm laminated glass; }\end{array}$ \\
\hline 2: & The number of specimen; \\
\hline 920: & Nominal height of specimen $[\mathrm{mm}]$; \\
\hline $0.5:$ & Rate of loading $[\mathrm{mm} / \mathrm{min}]$. \\
\hline
\end{tabular}

\subsection{Experimental procedure}

The load and vertical displacement of the upper crosshead of the INSTRON 5989 universal testing machine were continuously measured with Bluehill software during the tests of each specimen. At three different heights, the buckling displacement (horizontal displacement) of all specimens were continuously measured with $H B M$ displacement transducers during the tests. Strains at centre point on the surface of the glass panels were measured with HBM LY11-10/120 type strain gauges. The tests were carried out at room temperature $(+23$ $\pm 5^{\circ} \mathrm{C}$ ). At least three specimens were tested at each testing combination. The specimens were loaded until fracture. Laminated specimens were loaded until all glass layers were fractured. In total, 64 specimens were tested. The specimens were mounted as shown in Fig. 6.

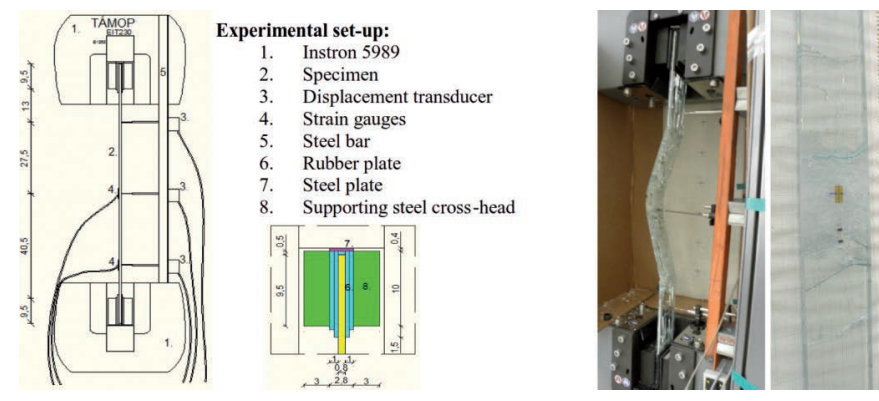

Fig. 6. Test set-up, fractured specimen and strain gauges

6. ábra Terhelési elrendezés, eltört próbatest és nyúlásmérö bélyegek

\subsection{Experimental results}

Loading force vs. displacement diagrams were prepared for the laboratory experimental results. Fig. 7 indicates the loading force vs. horizontal displacement in the mid-section of a specimen. Fig. 8 indicates the loading force vs. vertical displacements. In both Figs. 7 and 8 , three different stages can be distinguished in the buckling behaviour of the glass columns.
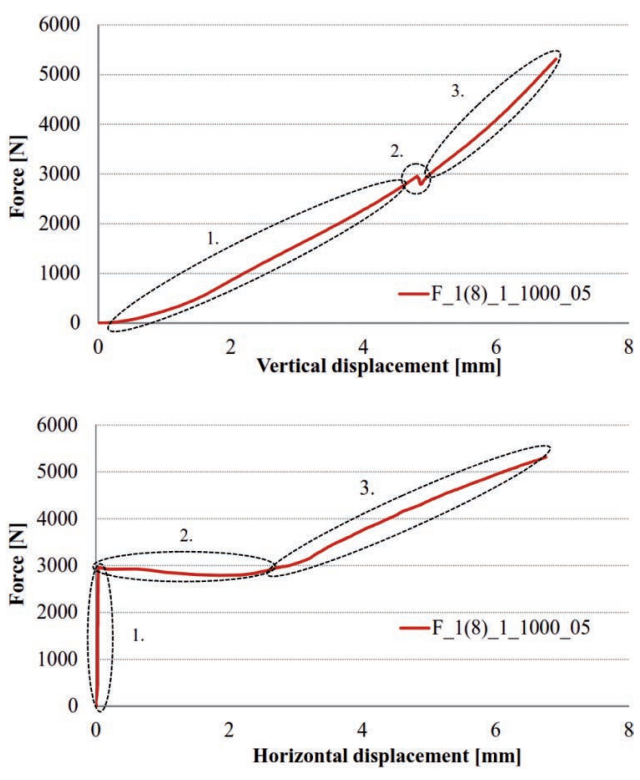

Fig. 7. a) Force vs. vertical displacement b) Force vs. horizontal displacement in the case of single float glass layer with thickness of $8 \mathrm{~mm}$ and height of $1000 \mathrm{~mm}$; Stages of buckling behaviour of a glass column

7. ábra a) Terhelö erő és függőleges elmozdulás összefüggése b) Terhelö erö és vízszintes elmozdulás összefüggése egyrétegü float, $8 \mathrm{~mm}$ vastag $1000 \mathrm{~mm}$ magas üvegek esetén. Üveg oszlop kihajlási alakváltozási szakaszai

In the $1^{\text {st }}$ Stage, the elastic deformation of the damping material (rubber plates) influences the vertical and horizontal displacements and no buckling occur (first stable stage). The $2^{\text {nd }}$ Stage is a short term stage which indicates a geometrical instable condition (in which direction the buckling will occur) and the specimen loses its former stability (bound phenomenon, instability). In the $3^{\text {rd }}$ Stage, both the vertical and the horizontal displacement increase until the fracture of the glass (second stable stage).

Fig. 8 indicates the force vs. vertical displacement curves of single and laminated glass specimens with total thickness of $12 \mathrm{~mm}$. To study the effect of the number of glass layers on the buckling behaviour, single layer glass specimens with thickness 
of $12 \mathrm{~mm}$ and laminated glass specimens consisted of $2 \times 6 \mathrm{~mm}$ or $3 \times 4 \mathrm{~mm}$ layers were tested as well. The critical load was found to be reduced with the increase of the number of glass layers. In the $1^{\text {st }}$ Stage, the glass specimens behave similarly, but significant difference can be observed in the $3^{\text {rd }}$ Stage. Before the fracture of the specimen, the force decreases with the increase of number of the glass layers in the case of glass columns consisted of laminated HSG glass layers and with a total thickness of $12 \mathrm{~mm}$. In the case of laminated glasses, the horizontal deformations and the load bearing capacity are influenced by the shear modulus of the interlayer material, therefore the force in the $3^{\text {rd }}$ Stage decreases.

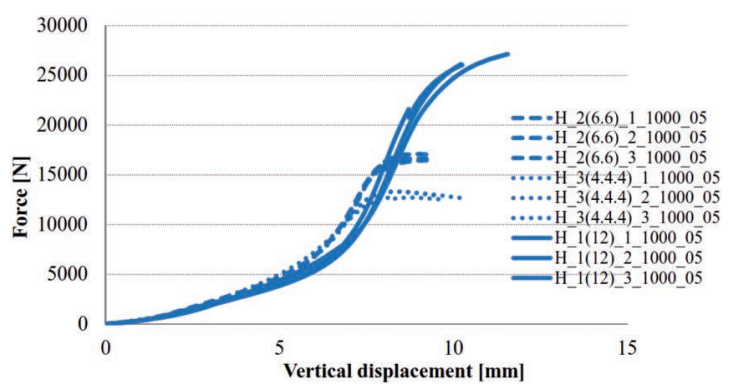

Fig. 8. Force and vertical displacement of HSG single and laminated glass specimens with total nominal thickness of $12 \mathrm{~mm}$ and height of $1000 \mathrm{~mm}$

8. ábra Terhelö erő és függőleges elmozdulás, azonos névleges $12 \mathrm{~mm}$ vastagságú 1000 m magas, hőkezelt üvegekböl felépülö oszlopok esetén

Fig. 9 indicates the force vs. horizontal displacement curves of laminated glass specimens consisted of $2 \times 4 \mathrm{~mm}$ HSG glass layers with $1000 \mathrm{~mm}, 920 \mathrm{~mm}$ or $840 \mathrm{~mm}$ nominal heights. The critical load and the $3^{\text {rd }}$ Stage was found to be reduced with the increase of the height of glass columns.

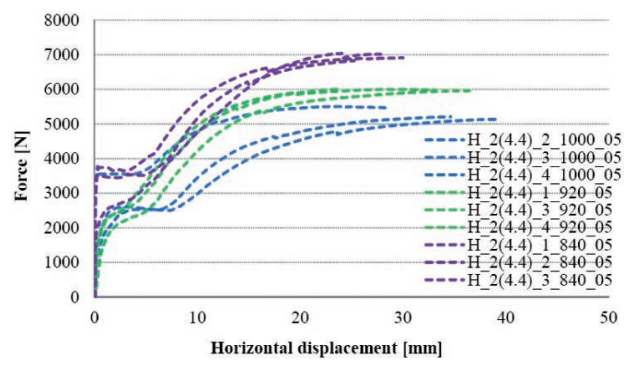

Fig. 9. Force vs. horizontal displacement of laminated glasses consisted of $2 \times 4 \mathrm{~mm}$ HSG glass layers with $1000 \mathrm{~mm}, 920 \mathrm{~mm}$ as well as $840 \mathrm{~mm}$ nominal heights

9. ábra Terhelő erö és keresztirányú elmozdulás összefüggése $2 \times 4 \mathrm{~mm}$ vastag hökezelt, laminált üvegekböl felépülö, 1000 mm, 920 mm, 840 mm névleges magasságú oszlopok esetén

Fig. 10 indicates the comparison in the buckling behaviour of laminated glass columns with the same height but consisted of non heat-treated float glass or HSG glass layers. In the $1^{\text {st }}$ Stage, the glass specimens behave similarly, the $2^{\text {nd }}$ Stage (bound phenomenon, instability) occurs at lower load levels in the case of float glasses, but significant difference can be observed in the $3^{\text {rd }}$ Stage. The $3^{\text {rd }}$ Stage lasted longer time in the case of HSG glass layers with increasing deformations and the force decreased before fracture of the specimen.

The buckling behaviour of laminated glass columns with the same height of $1000 \mathrm{~mm}$ and total nominal thickness of $12 \mathrm{~mm}$, consisted of $6+6 \mathrm{~mm}$ or $8+4 \mathrm{~mm}$ HSG glass layers are compared in Fig. 11. No significant difference in the buckling behaviour was observed by applying different thicknesses of glass layers but keeping the same nominal total thickness.



Fig. 10. Force vs. vertical displacement of laminated glasses consisted of $2 \times 4 \mathrm{~mm} H S G$ or float glass layers with height of $1000 \mathrm{~mm}$

10. ábra Terhelő erö és függöleges elmozdulás összefüggése $2 \times 4 \mathrm{~mm}$ vastag hökezelt laminált üvegekböl felépülö, $1000 \mathrm{~mm}, 920 \mathrm{~mm}, 840 \mathrm{~mm}$ névleges magasságú oszlopok esetén

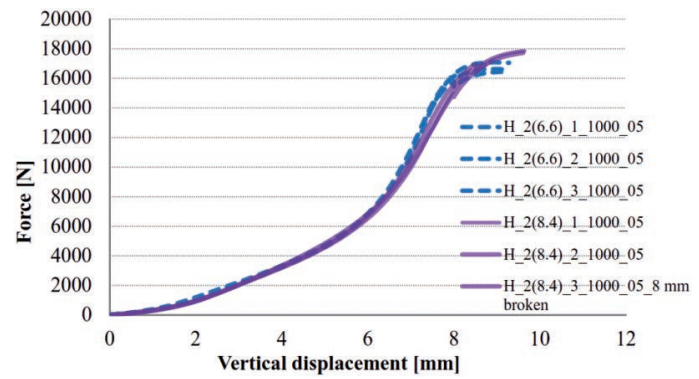

Fig. 11. Force vs. vertical displacement of laminated specimens consisted of $6+6 \mathrm{~mm}$ or $8+4 \mathrm{~mm}$ HSG glass layers with height of $1000 \mathrm{~mm}$

11. ábra Terhelö erö és függöleges elmozdulás összefüggése $(6+6 \mathrm{~mm}, 8+4 \mathrm{~mm})$ vastag hőkezelt, laminált üvegekböl felépülő, $1000 \mathrm{~mm}$ magas névleges magasságú oszlopok esetén

\subsection{Conclusions}

The following conclusions can be drawn for the presented experimental tests:

- Three different stages can be distinguished in the buckling behaviour of glass columns.

- The buckling behaviour is not affected by the loading rate in the case of loading rate of $0.5 \mathrm{~mm} / \mathrm{min}$ or $1 \mathrm{~mm} / \mathrm{min}$.

- The critical buckling load is reduced with the increase of the number of glass layers.

- The allowed buckling load during structural design calculations is suggested to be the maximum load of the $1^{\text {st }}$ Stage (stable stage) reduced with safety factors.

- The $2^{\text {nd }}$ Stage in the buckling behaviour is mainly influenced by the type of the supporting structure (fixed/pinned) and the stiffness of the glass columns.

- In the case of laminated glasses, the horizontal deformations and the load bearing capacity are influenced by the shear modulus of the interlayer material, therefore the force in the $3^{\text {rd }}$ Stage decreases.

Authors have quantitatively summarized the critical load $\left(\mathrm{N}_{\mathrm{cr}}\right)$ of the tested glass columns in Table 1. In the case of equal nominal thickness monolithic or laminated glass specimens, the critical load of laminated glass specimens is reduced with 25 to $40 \%$ compared to the monolithic (single) glass specimens. In the case of laminated glass that consists of three glass layers, the reduction can exceed $50 \%$. 


\begin{tabular}{|c|c|c|c|c|c|c|c|c|c|c|c|}
\hline \multirow{5}{*}{$\begin{array}{l}\text { Height } \\
\text { [mm] }\end{array}$} & \multirow{5}{*}{$\begin{array}{l}\text { Type of } \\
\text { glass }\end{array}$} & \multicolumn{10}{|c|}{ Critical load (Ncr) } \\
\hline & & \multicolumn{3}{|c|}{ Total thickness: 8 mm } & \multicolumn{7}{|c|}{ Total thickness: $12 \mathrm{~mm}$} \\
\hline & & \multirow{3}{*}{$\begin{array}{c}\text { Single } \\
\text { layer } \\
\mathbf{8} \\
\text { [N] }\end{array}$} & \multirow{2}{*}{\multicolumn{2}{|c|}{$\begin{array}{c}\text { Laminated glass } \\
4.4\end{array}$}} & \multirow{3}{*}{$\begin{array}{c}\text { Single } \\
\text { layer } \\
12 \\
{[N]}\end{array}$} & \multicolumn{6}{|c|}{ Laminated glass } \\
\hline & & & & & & & & & & & \\
\hline & & & {$[\mathrm{N}]$} & $\%$ & & {$[N]$} & $\%$ & {$[\mathrm{~N}]$} & $\%$ & {$[N]$} & $\%$ \\
\hline \multirow[t]{2}{*}{1000} & Float & 5672 & 3490 & 62 & 19803 & 14575 & 74 & - & - & 13425 & 68 \\
\hline & \multirow{3}{*}{ HSG } & 7506 & 5278 & 70 & 26420 & 16698 & 63 & 17495 & 66 & 12684 & 48 \\
\hline 920 & & 8784 & 5989 & 68 & - & - & - & - & - & - & - \\
\hline 840 & & 10207 & 6919 & 68 & - & - & - & - & - & - & - \\
\hline
\end{tabular}

Table 1. Critical load of glass specimens based on the experiments 1. táblázat Kritikus teher a kísérletek alapján

\section{Future work}

Authors are going to present the existing calculation methods of the critical load of glass columns, and are going to compare the results of the laboratory experiments and theoretical calculations in a separate paper in Épitöanyag - Journal of Silicate Based and Composite Materials.

\section{Acknowledgements}

Authors express their gratitude to Rákosy Glass Ltd. for providing the specimens. Authors are thankful to the Department of Construction Materials and Engineering Geology, BME and Mr. András Eipl (Struktúra Kft.) and Mr. Péter Molnár (Struktúra Kft.) for their technical support.

\section{References}

[1] Nehme K. - Nehme S.G. - Jakab A.: Üveg oszlopok kihajlása, (Buckling of glass columns) Müszaki Tudomány az Észak-Kelet Magyarországi Régióban 2013. Proceedings. Konferencia előadásai, szerkesztette: Pokorádi L., DE MK, 2013. június 4., DAB Müszaki Szakbizottsága, Debrecen, 2013, ISBN 978-963-7064-30-2, pp. 378-388.

[2] Pankhardt, K.: Különleges üveg tartószerkezetek a magyar építőiparban, (Special glass structures in the Hungarian building industry). Épitőanyag, 55(3) 2003, pp. 106-111.

[3] Pankhardt, K.: Üvegtartók, (Glass structures). Könnyüszerkezetes épités, 6(2), 2010, pp. 27-36.

[4] Pankhardt, K.: Load bearing glasses. Testing of construction glasses. Saarbrücken: Lap Lambert GmbH, 2012. -ISBN: 9783847321910

[5] Schittich, C. - Staib, G. 2 Balkow, D. - Schuler, M. - Sobek, W.: Glass Construction Manual. Birkhäuser Publishers, Basel, 1999, pp. 65-69, p. 102., ISBN 3-7643-6077-1

[6] Ádámkó, E.: Teherbíró üvegszerkezetek, üvegoszlopok, (Load bearing glass structures, glass columns). TDK 2009, (consultant: Pankhardt K.) University of Debrecen

[7] http://www.santambrogiomilano.it, (2013.04.04.)
[8] Pilkington Planar ${ }^{\mathrm{TM}}$ product catalog:

http://www.pilkington.com/north-america/usa/english/products/bp/ downloads/byproduct/glasssystems/default.htm (2013.05.30.)

[9] Wölfel, E.: Nachgiebiger Verbund eine Näherungslösung und deren Anwendungs-möglichkeiten. Stahlbau, No.6, 1987, pp.173-180.

[10] Blaauwendraad, J.: Buckling of laminated glass coloumns. Heron 52(1/2) 2007, pp.147-164.

Ref.:

Kinga Nehme - András Jakab - Salem Georges Nehme: Experiments on the buckling behaviour of glass columns. Part 1. Építőanyag, 65. évf. 3. szám (2013), 62-66. p. http://dx.doi.org/10.14382/epitoanyag-jsbcm.2013.13

\section{Üvegoszlopok kihajlásának laboratóriumi vizsgálata.}

1. rész.

Az üveg erôsítési eljárások fejlôdésének köszönhetôen ma már a tartószerkezetek is transzparensek lehetnek. Az építési üveg, mint sokoldalú építôanyag átlátszóságának köszönhetốen lehetôvé teszi az építészek törekvéseinek megvalósítását. Cikkünkben a teherhordó üvegek témakörén belül, az üvegoszlopok, lizénák kialakítási és teherbírási, stabilitási kérdéseivel foglalkozunk. Külföldi és hazai esettanulmányokkal bemutatjuk az üvegoszlopok keresztmetszeti, rétegrendi, megtámasztási és kialakítási lehetôségeit [1].

A BME Építôanyagok és Mérnökgeológia Tanszék laboratóriumában kísérleti úton vizsgáltuk az üveg oszlopok kihajlását. Több mint $60 \mathrm{db}$ próbatestet tönkremenetelig terheltünk. Mértük a terhelô erốt és az alakváltozásokat (kihajlás, felületi alakváltozások). Kísérleti eredményeink alapján meghatároztuk a kritikus erôt, erô-alakváltozás diagramokkal szemléltettük a tönkremeneteli és stabilitási folyamatokat. Eredményeink tükrében elemeztük a nemzetközi irodalomban fellelhetố számítási eljárásokat (melyeket a cikksorozatunk következố részében ismertetünk).

Kulcsszavak: üveg oszlop, kihajlás, teherbíró üveg, stabilitás, átlátszóság

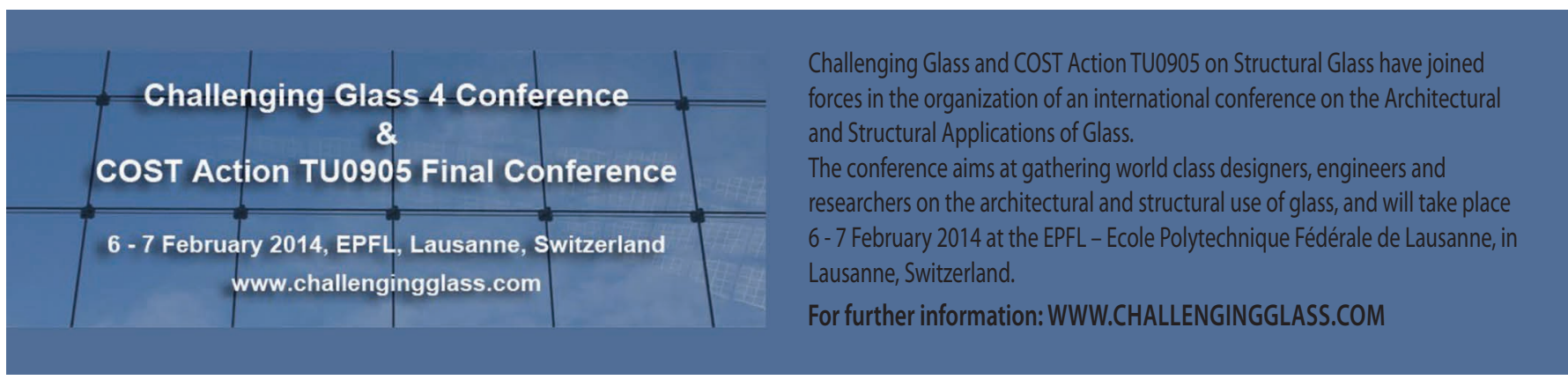

